\title{
Cytohistomorphological identification of congenital bilateral mesenchymal hamartoma of chest wall
}

\author{
Smita Mahapatar ${ }^{1}$, Asaranti Kar², Pallavi Bhuyan², Priyadarsini Biswal' ${ }^{2}$, Upasana Das², \\ Priyadarsini Dehury² \\ 1. Dept. of Transfusion Medicine, S.C.B. Medical College \& Hospital, Cuttack, Odisha State, India. 2. Dept. of Pathology, \\ S.C.B. Medical College \& Hospital, Cuttack, Odisha State, India.
}

Correspondence: Smita Mahapatar. Address: C/O- Mr. N.K. Mishra, N-1/256, I.R.C. Village, Nayapalli, Bhubaneswar, Odisha State, India, PIN-751015. Email: doctorsmita@rediffmail.com

Received: July 26, 2013

Accepted: September 10, 2013

Online Published: September 22, 2013

DOI : $10.5430 /$ jst.v3n5p7

URL: http://dx.doi.org/10.5430/jst.v3n5p7

\begin{abstract}
Cases of Congenital hamartoma of the chest wall in infants are rare and their bilateral involvement is extremely rare. An 18 month-old child presented with bilateral chest wall swellings since birth which were gradually increasing in size. The X-Ray of the chest wall revealed bilateral involvement of 1st, 2nd and 3rd ribs with involvement of extra-pleural soft tissues. The cytological diagnosis given was round cell tumor of the chest wall keeping in view the presence of round cells in a hemorrhagic background. The biopsy revealed areas showing mature cartilage, bone, fibrous tissues along with hemorrhagic cystic cavities. Basing on the biopsy report, final diagnosis of chest wall hamartoma was given. Following complete excision, the child was doing well and there was no recurrence of the lesion as observed in the follow-up sessions.
\end{abstract}

\section{Key words}

Chest wall, Child, Hamartoma

\section{I ntroduction}

Congenital mesenchymal hamartoma is a rare condition involving newborn infants, accounting for $0.03 \%$ of primary bone tumor cases ${ }^{[1]}$. It was first described as intrathoracic mesenchymoma ${ }^{[2]}$ which was later on replaced by hamartoma due to its benign nature ${ }^{[3,4]}$. It generally comprise of mixture of cartilaginous component, fibrous tissues and cystic cavities. In most of the children, the lesion noticed at birth gradually increases in size as seen in our case. But the child in the present report had bilateral masses involving both the sides of the chest wall which gradually increased in size, leaving her parents panicking. The increase in size of the chest wall mass can lead to respiratory distress in few rare cases ${ }^{[3]}$, but it was not seen in our case. Very few such cases have been reported in the English medical literature. Only two cases have been reported stating more than one site involvement of the congenital hamartoma in newborns \& infants ${ }^{[5,6]}$. In the present case report, we have enumerated the cytological and histopathological features of the bilateral involvement of this entity which is extremely rare. 


\section{Case report}

An 18 month-old female child presented with bilateral chest wall masses since birth which gradually increased to a size of $3 \mathrm{~cm}$ on right side and $2 \mathrm{~cm}$ on left side (Figure 1). The parents, being worried about the gradual increase in size, came to the clinician for consultation. These masses were not tender, rather were hard in consistency and fixed. The chest X-Ray of the child revealed bilateral expansive masses involving 1st, 2nd and 3rd ribs with cortical destruction and erosion (Figure 2). This was accompanied by extra pleural soft tissue mass. The hematological parameters of the child were within normal limits. Repeated fine needle aspiration cytology from different areas of the swellings revealed few clusters of round cells in a hemorrhagic background. The provisional cytological diagnosis given was round cell tumor of the chest wall keeping in view the clinical diagnosis of Askin's tumor and the patient was advised to go for biopsy.

Figure 1. Child presenting with bilateral chest wall swellings

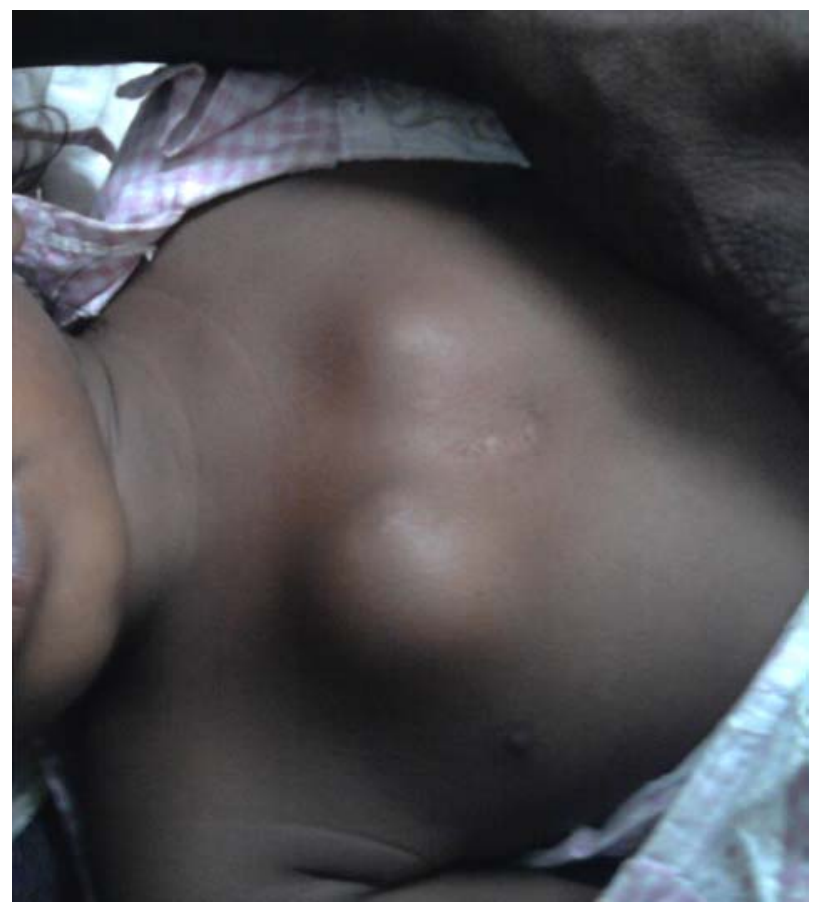

Figure 2. Chest X-Ray showing multiple ribs cortical destruction

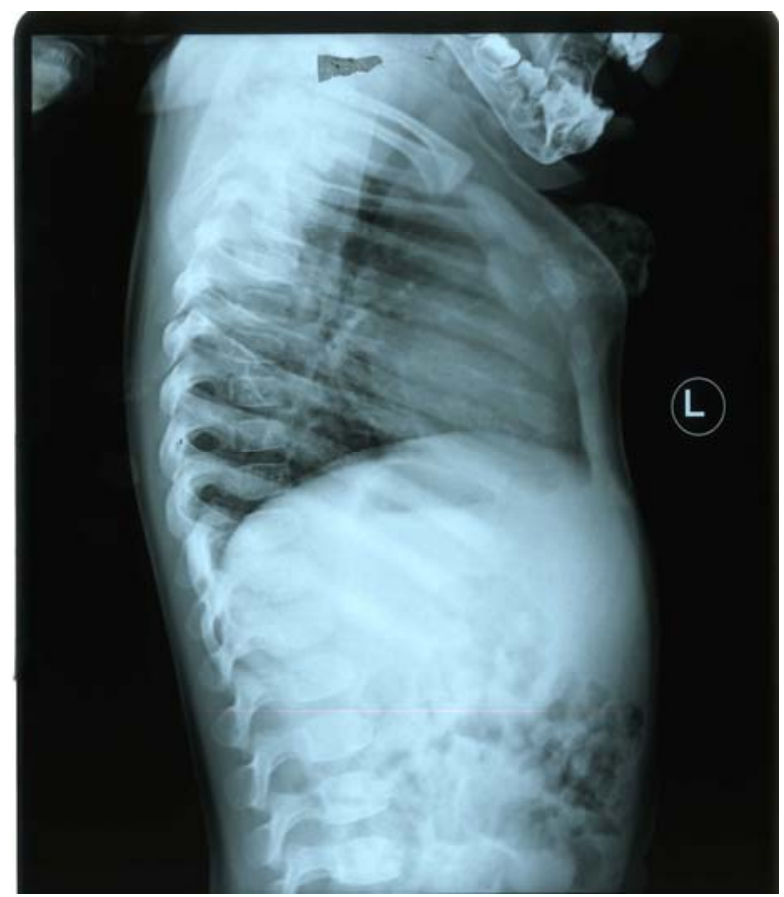


Figure 3. Microphotograph showing areas of cartilage, bone and fibrous tissues(100X, $\mathrm{H} \& \mathrm{E})$

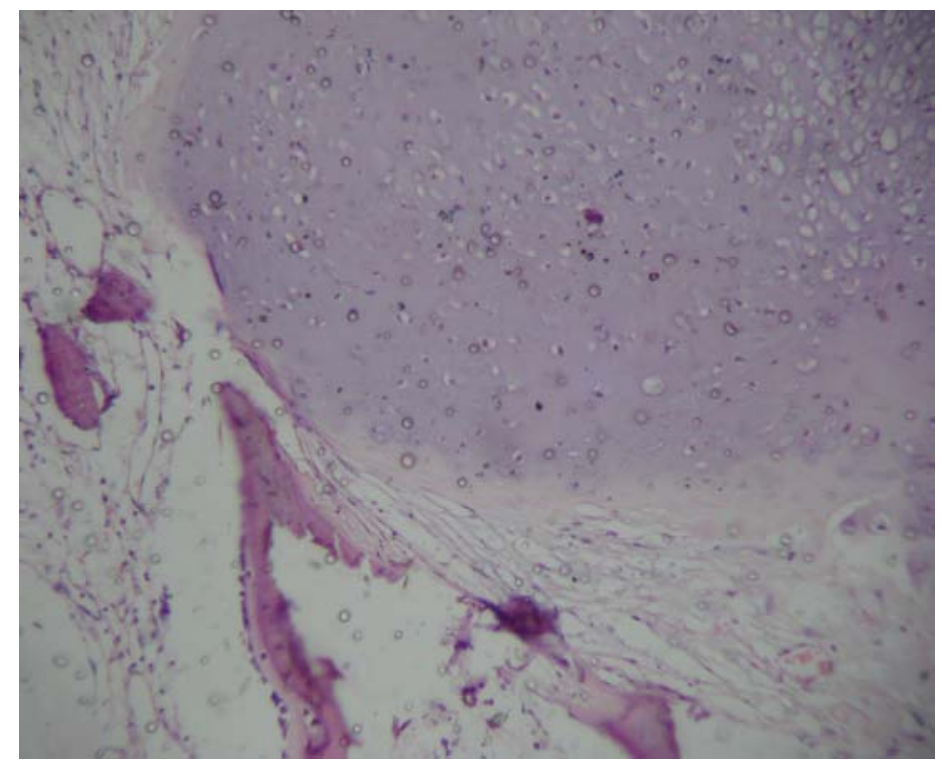

Figure 4. Microphotograph showing blood filled cystic space and cartilage $(400 \mathrm{X}, \mathrm{H} \&$ E)

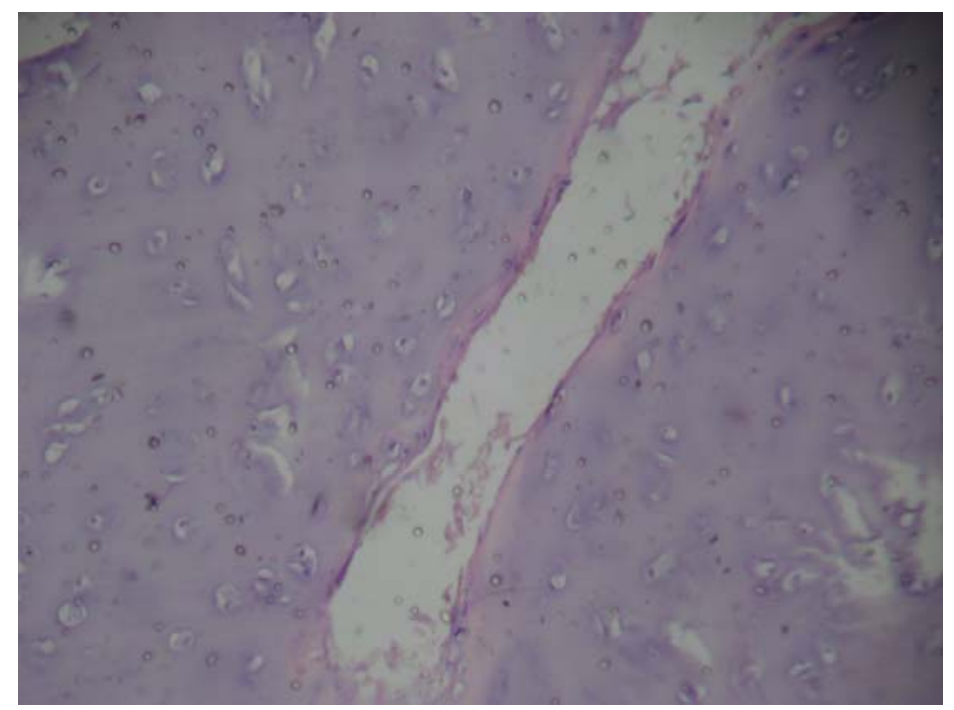

Both the masses were excised and the gross received showed irregular greyish white cartilaginous bony structures with attached fat measuring $6 \times 3 \times 2 \mathrm{~cm}^{3}$. Cut-section was gritty, whitish with greyish areas in between. Microsections revealed areas of cartilage, fibrous tissues, bony tissues, giant cells and few blood-filled spaces (Figure $3 \&$ Figure 4). The final histopathological diagnosis given was congenital mesenchymal hamartoma of the chest wall (B/L).

The child was followed up for a period of 12 months and it was found that she was doing well and there was no further recurrence of the disease.

\section{Discussion}

Although mesenchymal hamartoma of the chest wall is rare in infants and children, its bilateral presentation, as noticed in our case, is extremely rare. Other synonyms of this entity include mesenchymoma ${ }^{[7]}$, infantile osteochondroma ${ }^{[8]}$ and infantile cartilaginous hamartoma ${ }^{[9]}$. But, the currently accepted name of mesenchymal or chest wall hamartoma of chest wall proposed by Mc Leod and Dahlin in $1979^{[3]}$, is benign in nature with multiple histological components. 
Mesenchymal hamartomas are not considered as true neoplasms because they are composed of benign, mature cartilage, bone, fibrous tissues and hemorrhagic cavities and lack invasion or metastasis ${ }^{[12]}$.

Clinically, mesenchymal hamartomas are well circumscribed, painless mass arising from the central portion of the ribs which can involve and also erode adjacent ribs ${ }^{[6]}$. There is compression of the adjacent structures due to the size, expansion and extrapleural effect ${ }^{[10]}$. The chest X-Ray reveals large expansive lesion affecting multiple ribs with cortical destruction, erosion and extrapleural mass.

As many of the chest wall masses are malignant, accurate diagnosis of mesenchymal hamartoma is very important. The fine needle aspiration cytology (FNAC) of this lesion reveals lobules of hyaline cartilage, few spindle cells in an abundant chondroid matrix ${ }^{[11]}$. But, in our case, the cytology of the swellings revealed only few round cells found in a hemorrhagic background on repeated aspirations from different areas of the swellings. Thus, it was misinterpreted as small round cell tumor of the chest wall. Later on, the diagnosis was corrected in line with the biopsy findings. Many small round cell tumors including Ewing sarcoma, primitive neuroectodermal tumor (PNET) known as Askin tumor, can commonly occur as primary rib tumors ${ }^{[10]}$. In cytology, these reveal round cells in singles and sheets with rossetes formation.

Microscopic examination of mesenchymal hamartoma reveals mixture of proliferating cartilage, bone, spindle cells along with hemorrhagic cystic cavities representing secondary aneurysmal bone cyst (ABC) formation ${ }^{[12]}$. In our case, presence of mature cartilage, bone, spindle cells in sheets with cystic cavities have led to the histopathological diagnosis of mesenchymal hamartoma of the chest wall. Sometimes, the hypercellular proliferation of solid areas of proliferating mature cartilage and bone could mislead to the diagnosis of osteoblastoma, chondrosarcoma or osteosarcoma ${ }^{[13]}$. Chicken wire calcification seen in osteoblastoma and the malignant features like increased N: C ratio, hyperchromasia and nuclear atypia present in the latter two entities are notably absent in mesenchymal hamartoma ${ }^{[12]}$. The common benign lesions affecting ribs are fibrous dysplasia, and hemangioma. Though secondary ABC component can be seen in these conditions, but these are uncommon in newborns and Chinese letter pattern seen in fibrous dysplasia, lobular capillary proliferation in the latter dissect these from hamartoma.

Small, asymptomatic lesions do not require any surgical intervention which can be recommended in physical deformitity caused by hamartoma seen in our case and in cardiac or pulmonary compromise due to compressive effects of the mass ${ }^{[14]}$. Surgical intervention should be avoided as it could lead to severe blood loss and postoperative scoliosis. With close observation and proper investigations to diagnose mesenchymal hamartoma accurately, it can lead to the spontaneous regression of the lesion ${ }^{[2]}$. Cytopathologists should be aware of this rare lesion, as seen in our case in which we mistook this as round cell tumor in cytology for which the patient unnecessarily went through surgical excision. Histopathologists sometimes can misdiagnose the benign spindle cell elements in hamartoma as sarcoma in biopsy ${ }^{[15]}$. On histopathology, our case was correctly diagnosed as bilateral congenital hamartoma of the chest wall and on follow up, was seen to be doing well with no recurrence. While dealing with this type of presentation in a child, accurate diagnosis allows appropriate treatment which either consists of close clinical follow-up or surgical resection in symptomatic patients or lesions disfiguring the chest wall.

\section{Acknowledgement}

The authors express their deep sense of appreciation to Dr Jayasree Rath, Professor, Pathology, KIMS, Bhubaneswar , Odisha for all the valuable co-operation and guidance in the diagnosis and follow up of this unusual case report.

\section{References}

[1] Rao L, Kini AC, Valiathan M, Gurpur CR et al. Infantile cartilaginous hamartoma of the rib. A case report. Acta Cytol. 2001; 45(1): 69-73. PMid:11213507 http://dx.doi.org/10.1159/000327189 
[2] Blumenthal BI, Capitanio MA, Queloz JM, Kirkpatrick JA. Intrathoracic mesenchymoma: observation in two infants. Pediatr Radiol. 1972; 104(1): 107-109.

[3] Mc Leod RA, Dahlin DC. Hamartoma(mesenchymoma) of the chest wall in infancy.Radiology. 1979; 131(3): 657-61.

[4] Odell JM, Benjamin DR. Mesenchymal hamartoma of chest wall in infancy: natural history of two cases.Pediatr Pathol. 1986; 5(2): 135-146. http://dx.doi.org/10.3109/15513818609041196

[5] Troum S, Dalton ML. Multiple focal mesenchymal hamartoma of chest wall in infancy.J Pediatr Surg. 1996; 31(5): $713-715$. http://dx.doi.org/10.1016/S0022-3468(96)90684-3

[6] Okaley RH. Multiple benign mesenchymomata of the chest wall.Pediatr radiol. 1985; 15(9): 58-60. http://dx.doi.org/10.1007/BF02387856

[7] Eskeilenen M, Veli-Matti K, Vainio J. Mesenchymoma of the chest wall in children.Ann Thorac Surg 1991; 52(2): $291-293$. http://dx.doi.org/10.1016/0003-4975(91)91355-Y

[8] Seibert JJ, Rosi NP, McCarthy EF.A primary rib tumor in a newborn.J Pediatr Surg. 1976; 11(6): 1031-32. http://dx.doi.org/10.1016/S0022-3468(76)80087-5

[9] Balci P, Obauz F, Gore O, et al. Aneurysmal bone cyst secondary to infantile cartilaginous hamartoma of rib.Pediatr Radiol. 1997; 27(9): 767-769. PMid:9285745 http://dx.doi.org/10.1007/s002470050224

[10] Shamberger RC, Grier HE. Chest wall tumors in infants and children.Semin Pediatr Surg. 1994; 3(4): 267-276. PMid:7850367

[11] Mathur SR, Gupta R, Sith A, Agarwal S, et al. Aspiration cytplogy of mesenchymal hamartoma of the chest wall in an infant: a case report. Acta Cytol. 2010; 54(1): 63-65. PMid:20306991 http://dx.doi.org/10.1159/000324969

[12] Cohen MC, Drut R, Garcia C, Kaschula ROC. Mesenchymal hamartoma of the chest wall:a cooperative study with review of the literature. Pediatr Pathol. 1992; 12(4): 525-534. PMid:1409151 http://dx.doi.org/10.3109/15513819209024202

[13] Hall DP, Ellison RG. Osteochondrosarcoma of the chest wall in a newborn infant: a case report six years after surgery. Am Surg. 1964; 30(8): 745-747. PMid:14217113

[14] Campbell AN, Wagget J, Mott MG. Benign mesenchymoma of the chest wall in infancy. J Surg Oncol. 1982; 21(4): $267-270$. PMid:7144208 http://dx.doi.org/10.1002/jso.2930210416

[15] Castalleno VM, Fiano C, Vargas J, de Augustin P. Mesenchymal hamartoma of the chest wall. Cytopathology. 1997; 8(3): 210-219. 